\title{
Civil-Military-Islamist Relations: An Opinion on Democracy, Islamist Militancy and Praetorianism in Pakistan
}

\author{
Dr Arshad Javed Rizvi \\ Associate Professor, Sir Syed University of Engineering and Technology
}

\begin{abstract}
:
This research report has specially been written in the context, to highlight the relations between civil, military, Islamization and Islamists, their role and practices to remain in power and advancement of their views, and all these three have been alternatively cooperative and antagonistic. Pakistan has been under the military rule for more than half of its history, Pakistan is a young and violent nation and make struggle for its survival since inception. Due to the presence of Islamists and their dominant and violent activities, has caused unbearable damage to the democratic process in establishing strong, stable, advanced nation. These actors have played a crucial role in creating the Pakistan of today. What role a civilian government can play, while interacting with the ever present military and the Islamists.
\end{abstract}

Keywords: Islamization, Islamism, antagonistic, secular, military intervention, praetorians, nepotism

\section{Introduction}

Pakistan has been going through very loud period since its inception. During the period of independence, military played very important role and continuous political role ever since. Throughout the history of political system in Pakistan, influenced by military and its role has been facing criticism over the years. Since the war on terror, Islamists have been challenged for military, which were using Islam as an instrument to achieving their political objectives.

On the part of secular and religious forces, and the creation of many civil tremendous efforts have been made. Still we see no effective institutional counter balance to the military. Some military leaders operate these forces to their own interests, through developing effective links with civil society and these forces. These Islamist were supported through the Islamization process of Zia-al-Haq during the period 1977 to 1988, in result empowered these groups. Military regime controlled and influenced foreign and domestic policies. Dynamics of the military-islamists relationship changed after the eleven September events that brought a war at home, greatly damaged the future of democracy in Pakistan due to internal war. The present picture of Pakistan is due to the role of many factors behind. First one was the kind of foundation Pakistan built upon due to violent split of Indian sub-continent in 1947 was a British colony ruled almost one hundred years this period also called Births Raj. Hindu remained in India and Pakistan was created for Muslims of Indian Subcontinent. It was a largest migration based upon brutal and vicious killings of 200,000 to one million people during the actual migration between the month of August and September 1947, called "Partition". Muslims Left a legacy that has been felt more so in Pakistan than in India. India occupied infrastructure, institution and governmental systems of British Raj time where as Pakistan had to start from scratch and self governance, at that time only military institution was for assistance, to create the initial setup of government system. After 67 years of independence Pakistan is still weak and fragile still have the effects of devastation of partition. This was the main reason that we see military hold and influence in the governance of country from the beginning, became an example of relations between a dominant military and weak civil government and society.

Methodology

This research will mainly be based on qualitative method. For this purpose, different methods will be adopted. Descriptive methods will be used to describe characteristics of Pakistani population, its social cultural conditions to analyze the existing situation. This study will be based upon interviews, surveys, interrogation; secondly through exploratory method effort will be made to understand the causes of the situation. Third, the approach will be explanatory method to explain and analyze the research problem.

\section{Civil Military Relations; A theoretical Analysis:}

Military intervention is not only the case in Pakistan, many countries in the world have been experiencing interventions in their political governmental system, some have established successfully in to civilian governments, some are still facing cyclic regular military intrusion. The case with Pakistan is different in a sense, witnessed a military intervention into political governmental system since its inception, through direct or indirect control of government, showing tremendous influence, resulted the instability during the history of Pakistan and clash of unbalanced relations ship between the civil system and the military establishment, pulling failure of civil institutions to flourish.

Well known researcher, Samuel Huntington, States, military's encroachment into governmental affairs can only be eliminated by establishing strong civil supremacy. Political institutionalization is the back bone of 
strong stable political system; it has four features to measure the institutionalization of a political system. Namely, autonomy, complexity, adaptability and coherence in the presence of all these elements, civil society, political government military and other institutions work together in harmony to create civil supremacy.

\section{Civil Institutions or Institutionalization:}

Samuel Huntington defines institutionalization as a "Process by which organizations and procedures acquire value and stability". (Huntington, 2006, P.12).

Developed and under developed political system can be distinguished through number, size and effectiveness of its organizations. (lbid, P.12). In every society there are four features of institutionalism, the first one is adaptability-rigidity of an organization in a society, its survival depends on the level of adaptability and organization will be more likely to survive. An organizational adaptability is measured through an approach called "generational gap". It is very important a successful transfer of power during the lifetime of an organization otherwise adaptability becomes less likely. Amount of complexity or simplicity in an organization is the second feature of institutionalism more complex organization is considered to be highly institutionalized e.g. United States. Within an organization, the amount of autonomy or subordination is the third feature of institutionalism, scale to measure independence an organization has from non-political actors, such as military. Well developed societies have highly institutionalized, the political organization is highly autonomous, on the other hand societies with weak autonomy are extremely susceptible to outside actors e.g. military. The level of coherence or disunity in a society is the fourth feature of institutionalism. The political system that show the ability to coordinate and discipline have been highly institutionalized because it is crucial to politics. The chances of the influence of out side entities are less likely if all four features efficiently exist in the society, have the ability to provide needs of the civil society required for their success. Huntington's two approaches to minimizing military power one is "Subjective Civilian Control", a kind in which one organization maximize its power over all other civilian institutions in the civil society, but there can be a tussle for power control between the civilian groups. The dominant civil group manipulates the military in order to protect its own interests. Military cannot be able to show or have an independent entity, which not a healthy sign for the well-established civil society. The second approach is the "objective civilian control" in which military professionalism is most important, the civil society makes military a tool of the state through maximizing the professionalism of the military, in this approach military enjoy a separate, autonomous entity work operates independently of the civil society.

"Making the military professional the state makes them politically sterile and neutral". (Huntington, 1957, P.84) Their place and role becomes quite clear for them to serve in the society, but this approach is difficult to create, particularly in non-western nations.

Gabriel Almond and G, Bingham Powell contributes to Civil Supremacy, discuss sub-system autonomy and structural differentiation in civil societies. "Sub-systems" for an example pressure groups, political parties, mass media must be independent of the government, the amount or level of independence these actors have or avail from the governmental structure, more autonomous sub-system will be, where as in weak societies these actors are sub-ordinate to the government compared to strong civil system, allow outside actors to easily infiltrate the government and use their power for their own interest.

Defining "structural differentiation" contains development of new roles and sub-systems; it's a principal aspect of development or transformations of a political system, also deals with the changes that can occur in the relationship between roles, structures or between sub-systems. Almond and Powell believe that United States has highly differentiated political system "Political functions are to be performed by multiple highly specialized structures; communication is controlled by the mass media; political recruitment is done by the electoral and party structures; interest articulation, by a large variety of groups". (ibid, P.31).

Sub-system autonomy and structural differentiation are inter-dependent and at the sometime these two aspects of political development are extremely important to the health of a government system and to understand the level of institutionalization there is a requirement of strong civil institutions and how they lead to a heather government system.

\section{The Military Establishment}

Huntington is a famous researcher on civil-military relationships opens the door to number of theories, explains the military mindset of having entitled to entering the political realm and discusses praetorianism, patriarchy, patrimonialism and new-patrimonialism. Huntington believe that in a weak civil society and strong military relationship, praetorianism is a key component. He defines "praetorianism as the military's interference in their country's political system”. (Huntington, 2006, P.195)

A praetorian society which has no effective institution, political action is taken by social groups directly to achieve their goals, socially is kind of a free-for-all in such case army controls, the instruments of force and likely to be most successful (clap ham, 1985, P.139) 
When there are ineffective political institutions, not capable of refining, mediating and moderating group political action means power is fragmented, result in military's presence. Fragmented power comes in many forms and in small quantities. The weak of political institutions and authority over the system is transitory, means authority and office can be easily acquired and easily lost, military presence can stunt and prevent the growth or progress of political and economic institutions in the civil society. The idealist view of military behavior is that they can leave the praetorian environment if they allow or use the political system to do so. If the leadership power does not allow them, means they are confident to do what is right and help their country to create strong civil institutions and build a healthier civil-military relationship.

To analyze the military government weaknesses, it is not in their training to establish political organizations or effective political institutions by military politicians. Military skills are unfit to the sphere of politics because compared to army society is more complex. To run and creating the political institutions, leadership must have political skills rather than functional specialization, and these political skills can only be achieved through years of service in the public sector.

The two main political weaknesses of the military, their inability to run the society properly and the second one is their lack of legitimacy managing and administrating the developing societies, for military is easier that only includes system of provisioning, Supply, communications education and engineering, this could be enough to manage and run a developing nation state. But on the contrary in more advanced nations military cannot be able to cope with having the basic technical skills no longer match up to the demands of growing nations.

Advanced nations have high level of economy and stable, well established institutions and for military it becomes difficult to handle, result in mismanaging the nation due to lack in experience in this field, need to be run and administered by experienced political leaders. "the strongest is never strong enough to be always the master unless he transforms might into right and obedience into duty". (Finer quotes J. Rousseau). Military time in power may will become short lived unless makes efforts legitimizing its presence in the government. There are different types of military regimes. According to Finer, defines "a set of techniques used by the military to carry out their policies rather than as political or constitutional structures". The "first" type is called "indirect rule" means keeping the civilian government in control, military more often black mails the civilian government or remove ruling civilian government for another. The "Second" type of military regime is dual rule represents rule of both military and civilian rule, having qualities of both direct and indirect rule. The "third" type of military regime is direct rule, shows complete control over civilian government by removing it and taken complete control of the country. All these three types describe the level of military intervention into the political government realm.

\section{Civil Military Relations in Pakistan}

Since its birth, Pakistan has been a victim of too power full military. In the history of Pakistan military has a greater part of role in the political system since 1947, Pakistani has been lack in civil supremacy, due to lack of established civil institutions create space for the military intervention into the civil society. Military rule becomes the reason for the underdevelopment of institutions and government system, due to their intervention country has been deprived of being maturing into a strong political system. To develop healthy balance between its military and civil institutions, Pakistan must have, firstly, to establish civil supremacy to strengthen political system, this will be the first step towards the creation of country, if military allows then there will no longer need to rely so heavily on its military establishment.

\section{Islamization and Military}

Islamic agendas were introduced by the military leaders to solidify and justify their leadership position and in return kept the Islamists satisfied.

\section{Zia-ul-Haq's Islamization in Pakistan}

Zia mentioned in his first speech, about PNA'S protest (Pakistan National Alliance) due to rigging in March 1977 general election, that it is the time to bring Islam into the fore front of the government and there is a need Pakistan must sticks to "Islamic system". PNA'S roits created full space for military into power, Zia not only attained power in the result of mosque-military alliance but also worked to strengthen himself for the next, eleven years. Zia's Islamic Pakistan brought implementation of Zakat collection in 1980, established sharia (religious) Courts for the purpose of providing Islamic justice, he also brought change in the primary and secondary education, text books were rewritten with an Islamist ideological agenda and role of madrassas became more important, their diplomas became equivalent to a university degree making the madrassas candidates eligible for government jobs. He wanted to Islamicizing the country at a fast rate. 


\section{Islamization of Pakistan under Pervez Musharraf}

Pervez Musharraf had hesitant acceptance for the Taliban in Afghanistan, contended that there version of Islam is based on ignorant and primitive, not accepted by Islamic world. His support for Taliban regime was in the national interest and security issues of Pakistan, on the western border from Afghanistan and on the eastern border with India, would be difficult to handle at both fronts. His first speech after coup, "The clergy to curb elements which are exploiting religion for vested interests and bring bad name to our faith". First of all, he tried to take action to reform the "Blasphemy Law" in April 2000. Musharraf had to back down due to an uproar of Islamic parties over this procedural change.

Musharraf expressed his opinion about religious extremism during a speech he gave to religious scholars and clerics in June, 2001. "Is there any doubt that we have been left behind although we claim Islam will carry us forward in every age, every circumstance and every land...How does the world judge our claim? It looks upon us as terrorists. We have been killing each other. And now we want to spread violence and terror abroad. Naturally the world regards us as terrorists. Our claim of tolerance is phony." Before \& after 9/11, Musharraf saw distinction between Kashmiri Islamists and Islamists. There was a distinctions between "terrorists" (Al-Qaeda members) and "freedom fighters" (Kashmiri militants) got favoritism from Musharraf"s regime because their fighting is justified in Kashmir to freeing the Kashmiris from Indian unjust rule. Fear of retaliation from extremist was holding him back. After the incident of 9/11, Musharraf stance completely changed about Taliban, due to the United States pressure on Musharraf either align with the west or become the enemy. Musharraf had to take historical decision for supporting U.S Military campaign. Domestically he had to take measures to limit religious groups and license of the Mullahs. Doing so Musharraf became on the target list of Islamists and had to face the threats of assassination attempts after 9/11. Indian parliament became the victim of their relation December 13, 2001. Indian responded threatening in war alone 1800 mile border with Pakistan. Many members of terrorist group were arrested, but finally in a speech Musharraf declared that he would not allow terrorism for the cause of Kashmir, hundreds of militants who were arrested released after few days later because ISI (inter services intelligence) did not want to keep their Jihadi partners in prison for too long, they knew that government needs them. Due to assassination attempts on Musharraf within eleven days, government had to take drastic measures, many militants were arrested and killed, ISI had to pay substantial amount of severance pay to jihadi leaders, Hafiz Mohammad Saeed (Lashkar-e-Taiba), Maulana Masoon Azhar (Jaish-eMohammad) and Maulana Fazlur Rehman Khalil (Harkatul Mujahideen) in return for their agreement to remain dormant for an unspecified duration, ISI was working independently though it's a branch of military, having its own agenda separately, it had close relationship with militants, became larger and powerful then military. Pakistan government and the militants have been enjoying good relationship to meet their needs, military government used to use them to create chaos and gives the chance or space to step in and take over the government, in return military establishment gives them protection and special treatment to militants, so that government can enjoy power advantage, at the same time militants safeguard their power not to be forgotten, the role of ISI and the Islamists has been crucial link between the military and the Islamists. These relation have been responsible that have jeopardized any chance at democracy in Pakistan.

\section{Islamism and Islamists in Pakistan}

Pakistan military has been playing a key role in giving Pakistan an Islamic identity. Pakistan was founded on the base of religion Islam to have separate nation having Islamic ideology. The wars between India and Pakistan and Russians invasion in Afghanistan the rallying cry or slogan was Islam, to get support from masses. In Pakistan large number of Islamists uses political parties to achieve their goals. One of them oldest in the history of Pakistan is well known "Jamaat-e-Islami". All Islamic political parties gained some power in the parliament and some of them aligned with military establishment to promote their own agenda in Pakistani politics. Jamaat-eIslami was founded in 1941, six years before independence and still active in politics, its founder was Maulana Maududi, and he believed Islam is a complete ideology as a religion and continues the mission of the prophets, this mission was as follow:

- To revolutionize the intellectual and mental outlook of humanity and to instill the Islamic attitude toward life and morality to such an extent that their way of thinking, ideal in life, and standards of values and behaviors become Islamic.

- $\quad$ To regiment all such people who have accepted Islamic ideals and mold their lives after the Islamic pattern with a view to struggling for power and seizing it by the use of all available means and equipment.

- To establish Islamic rule and organize the various aspects of social life on Islamic bases, to adopt such means as will widen the sphere of Islamic influence in the world, and to arrange for the moral and intellectual training, by contact and example, of all those people who enter the fold of Islam from time to time.

To achieve their own goals, the Muslim League and Jamaat used each other, resulted in legitimizing the political 
function of other to promote their communalist cause. Maududi wanted to regiment the Muslim population and mould their thinking a belief system, for him it was very necessary to remove out the creases in the design of the nation unity by the religion of its citizens. In the environment of chaos and power struggles, idealist thinking or views are not practicable therefore for a man like Maulana Maududi, Pakistan wasn't a suitable place. Author Husain Haqqani quotes Sayyed Nasr, "The Jamaat legitimated communalism in Islamic terms and helped the League find a base of support by appealing to religious symbols. The Muslim League, in turn, increasingly Islamized the political discourse on Pakistan to the Jamaat's advantage, creating a suitable gateway for the party's entry into the political foray. Leaders wanted to use "Maududi's ideas who wanted to inspire a large group of Muslims, who would not want power but would lead by example". But not wanted to accept Maududi as the representative of the ideas. He was seen as rival claimant of popular support, totalitarianism in his concept of pious leadership and Jamaat-e-Islami's revolutionary rhetoric dangerous by the Muslim League leaders. Maududi felt that they are not the right leaders to lead the nations, only his party has the pious individuals to represent the country and Islamic constitution.

In 1956, first constitution was adopted by Prime Minister Mohammad Ali the official name of Pakistan became, "The Islamic Republic of Pakistan", he was credited by Maududi's followers. In 1947, Islami Jamaat-eTalaba, Islami students society (IJT) was founded at university level organization but with the time JT became more political than it had under the guidance of Maulana Maududi. In 2002 elections, the Muslim League decided to join the Islamists parties under the name of Muttahida Majlis-e-Amel (MMA), scoring 18 seats in the parliament and also gained control of the "NWFP" region Khyber Pakhtun Khoa. This control "Made this region a breeding ground for religious extremism, shaping the fundamenlist's leanings of their Afghan neighbors, the Taliban". (Shuja, 2008, P.532)

\section{Russian Invasion of Afghanistan: Islamic Militant Role:}

"The American assistance to the Afghan Mujahideen, which kept increasing, was a critical factor in tilting the operational balance against the Soviet Union "During the war, Islamists grew in number and power, due to the assistance of Pakistan's military branch ISI. Islamists started considering it as a "Jihad" because war is against non-Muslim nation. And they were perfect recruits for ISI to carry on their own agenda. The ISI were instrumental in educating and training the Islamists, along with large numbers of Afghani refuges came into Pakistan. Islamists got involved in ongoing Kashmir conflict and sunnis-shias sectarian violence. During the Afghanistan war with Russia, Madrasses played crucial role religious individuals were churning out to fight with communists. Along the Afghan Pakistani border, Zia established a Chain of deeni Madaris, in order to create a belt of religiously oriented students to help Afghan Mujahiden to evict soviets from Afghanistan. After this these trained Islamists migrated to Kashmir to fight with another enemy India, as a freedom fighters. But Afghan extremists were called terrorists. After the incident of 9/11, due to pressure from, United States both groups were called terrorists.

\section{Sectarianism and Islamism}

To legitimize the role of military intervention, military manipulates the sectarian and ethnic divisions. Which has played a significant role to create praetorianism through civil military alliances? Sunni and Shia in Islam are two largest sects, Sunni believe Prophet Muhammad named his successor, Abu Bakr and Shia believe next leader ought to be from the bloodline of the Prophet, who would leadership the Islamic Empire. There has been many sectarian violence, creates bitter divide and instability and killing of innocent people and religious fanaticism. Ethnic divisions have been causes violence in Pakistan. Greater percentage is Muslim but their ethnic origin is more important and meaningful than their religion. Since 1980 to 1992 there has been ethnic violence between Sindhis and minority mohajirs.

An example of how the military manipulates ethnic tensions follows, "the widespread ethnic clashes in Karachi between Mohajirs on the one side and the Pathans and Punjabis on the other in the mid and late 1980s (during Zia's rule) were widely believed to have been engineered by the intelligence agencies in order to maintain the need for military rule"

To sustain their power over the country, it is quite depressing and discouraging to see the military and the Islamists use violent measures against the population.

\section{Contemporary Islamist Attacks and Conflicts}

Much recent time, conflicts have shown Islamist involvement having connection with Pakistan. Indian Mumbai was victim to terrorist attack on November $26^{\text {th }}$,2008; it was a big target attack at five different locations in the large city. Two hotels, a restaurant, a Jewish center and a train station were targeted, killing 173 persons by ten gunnies. India stated, involvement of Lashkar-e-Taiba was responsible, to jeopardize any hope of friendly relations between Pakistan and India by Islamist militant group.

At northern, Pakistan Swat Valley is situated bordering Afghanistan. In early May 2009 conflict arose 
between Taliban based in this area and the Pakistan military, it was due to the breach of peace deal between and attempt of Taliban to expand their area of control. Their intention was to make Pakistan Islamic nation to their liking started infiltrating. According to the BBC's Shoaib Hasan, the ISI created the Taliban to create a larger military to combat India's massive military size. The ISI strategy saw that having Afghanistan would allow for the Pakistani military to have, "geographic strategic depth in case of war with India"

Taliban think that their way of life is best to run the Pakistan; on disagreement they express their feelings through violence. To discuss their disagreements with democratic political system does not seen feasible, they are responsible for highly damaging the democrats' process in Pakistan, assassination of Benazir Bhutto and the Swat Valley conflict are examples to destroy the democratic process in Pakistan.

\section{Conclusion}

During recent years, terrorist activities in Pakistan has been on the front line, the military the Islamists and the civilian system have been involved in this, an ever changing landscape. Military infiltration into governmental system is totally due to the absence of strong civil institutions in Pakistan. To get advantage from the governmental system, Islamist used military's large role in the government system, and promoted their own agenda through military establishment to safe guard their distorted version of Islam, have been creating unrest to keep the nation unstable. The successful offensive measure in Swat Valley has lead Pakistan in a new direction, presently Zarb-e-Azab under the direction of Chief of Army Staff General Raheel Sharif is going on successfully to eliminate extremists. To gain better future effective strong civilian institution must be established, at the sometime military and Islamists ought to step back, from playing any role in the political domain, so that civil institutions must get strong growth. There is a need of genuine leader from the populace who could inspire the people these must be end of practices of nepotism and patrimonialism, these practices are the main hindrances in the way of Pakistan's progress, and focus must be given to the system of meritocracy, allow someone to come up from the populace. If Pakistan stays on the current path, it will remain unstable haven for the extremists and the military. The status quo only serves those, currently hold power and allows the subjugation of the citizens. If the people of Pakistan want a just government that truly serves its populace must adopt the true system of meritocracy, and over throw the vested powers that have been ruling Pakistan since its birth.

\section{References}

Abbas, H. (2005). Pakistan's Drift Into Extremism. London: M.E. Sharpe.

Almond, G. a. (1966). Comparative Politics: A Developmental Approach. Boston:Little, Brown, and Company.

Arif, G. K. (1995). Working with Zia: Pakistan's Power Politics 1977-1988.

Karachi: Oxford University Press.

Clapham, C. (1985). Third World Politics: An Introduction. Madison: University of Wisconsin Press.

Finer, S. (1988). Man on Horseback. Boulder: Westview Press.

Haleem, I. (2003). Ethnic and Sectarian Violence and the Porpensity Towards Praetorianism in Pakistan. Third World Quarterly, 24 (3), 463-477.

Haqqani, H. (2007). Pakistan and the Islamists. Current History, 147-152.

Haqqani, H. (2002). Pakistan: Between Mosque and Military. Washington, D.C.: The Carnegie Endowment for International Peace.

Huntington, S. (2006). Political Order in Changing Societies. New Haven: Yale University Press.

Huntington, S. (1957). The Soldier and the State. Cmabridge: The Belknap Press of Harvard University Press.

Jones, O. B. (2002). Pakistan: Eye of the Storm. New Haven: Yale University Press.

Maniruzzaman, T. (1987). Military Withdrawal from Politics. Cambridge: BallingerPublishing Company.

Pakistan Army in Taleban City. (2009, May 23). Retrieved May 27, 2009, from BBC: news.bbc.co.uk/2/hi/8065062.stm

Pakistan Conflict Map. (2009, May 24). Retrieved May 27, 2009, from bbc.com: http://.bbc.co.uk/2/hi/south asia/8044604.stm

Shuja, A. (2008). Crossed Swords. Oxford: Oxford University Press

Ziring, L. (1998). Pakistan in the Twentieth Century: A Political History. Oxford University Press. 